\title{
The Little Auk Alle alle: an ecological indicator of a changing Arctic and a model organism
}

\author{
Katarzyna Wojczulanis-Jakubas ${ }^{1}\left[\right.$ [D $\cdot$ Dariusz Jakubas $^{1}\left[\mathbb{D} \cdot\right.$ Lech Stempniewicz $^{1}(\mathbb{C}$
}

Received: 26 April 2021 / Revised: 23 November 2021 / Accepted: 30 November 2021 / Published online: 13 December 2021

(c) The Author(s) 2021

\begin{abstract}
The Little Auk Alle alle is a small planktivorous auk breeding colonially in the High Arctic. Owing to its large population size and bi-environmental lifestyle, resulting in the large-scale transport of matter from sea to land, the Little Auk is one of the most important components of the marine and terrestrial ecosystems in the Arctic. As a result of globalization, which facilitates access to remote areas of the Earth, a growing number of studies is being dedicated to this endemic Arctic seabird. Research has focussed primarily on the importance of the Little Auk as an ecological indicator reacting to the climatic and oceanological changes that are particularly evident in the Arctic as a result of Arctic amplification (warming is more rapid in the Arctic than in any other region on Earth). Importantly, the species is also used as a model to investigate matter and energy flow through the ecosystem, mate choice, parental care and biological rhythms. Here, we review the natural history of the Little Auk, highlighting studies with the potential to provide answers to universal questions regarding the response of seabirds to climate variability and avian reproductive behaviour, e.g. threshold of foraging flexibility in response to environmental variability, carry-over effects between the breeding and non-breeding periods, the reasons for the transition from bi- to uni-parental care, parental coordination mechanisms.
\end{abstract}

Keywords Seabird $\cdot$ Climate change $\cdot$ Marine ecosystem $\cdot$ Global changes $\cdot$ Sentinel

\section{Introduction}

The Arctic is a unique region on Earth, characterized as it is by a lower biodiversity and less complex food webs compared to those encountered at lower latitudes (Gauthier et al. 2011; Legagneux et al. 2012). Such a system offers an excellent platform for various studies on behavioural and evolutionary ecology that would be hard to perform in more complex environments. It serves as a natural laboratory where one can carry out experiments under fairly controllable circumstances. The uniqueness of the Arctic is also highlighted in the context of ongoing climate changes, as this region is disproportionally affected by climate warming, a phenomenon known as Arctic amplification (Serreze and Barry 2011; Zonn et al. 2017; IPCC 2019). This is bringing about major changes to ecosystem productivity and species

Dariusz Jakubas

biodj@univ.gda.pl

1 Department of Vertebrate Ecology and Zoology, Faculty of Biology, University of Gdańsk, ul. Wita Stwosza 59, 80-308 Gdańsk, Poland distributions (Holland et al. 2001; Steinacher et al. 2009; IPCC 2019), to which endemic species, adapted to harsh Arctic conditions, are particularly susceptible. Such species are therefore often excellent models for monitoring the condition and health of this polar environment.

The Little Auk or Dovekie Alle alle (Fig. 1) is one such endemic Arctic species. It is a small planktivorous auk, one of the most numerous seabirds of the Palearctic. The Little Auk breeds colonially amongst rock crevices on mountain slopes, exclusively within the seacoast zone of the High Arctic (Stempniewicz 2001). Taxonomically, it is unique in its genus but belongs to the Alcini tribe, together with Brünnich's Guillemot Uria lomvia, Common Guillemot Uria aalge, Razorbill Alca torda and the extinct Great Auk Pinguinus impennis (Smith and Clarke 2015). The Little Auk's abundance [ $>37$ million pairs worldwide (WojczulanisJakubas et al. 2011b; Keslinka et al. 2019)] and position in the trophic network-being the only exclusively zooplanktivorous seabird in the Atlantic sector of the Arctic, it is an important consumer of zooplankton in this region-means that it plays a major ecological role in the Arctic marine ecosystem. For this reason, the Little Auk has been selected for 
Fig. 1 Breeding cycle of the Little Auk (from left to right and top to bottom): copulation/ mating (photo Tomasz Kasiak), egg in the nest chamber/incubation, an adult feeding the chick/ chick rearing and a group of adults in the colony (photo Cornelius Nelo)

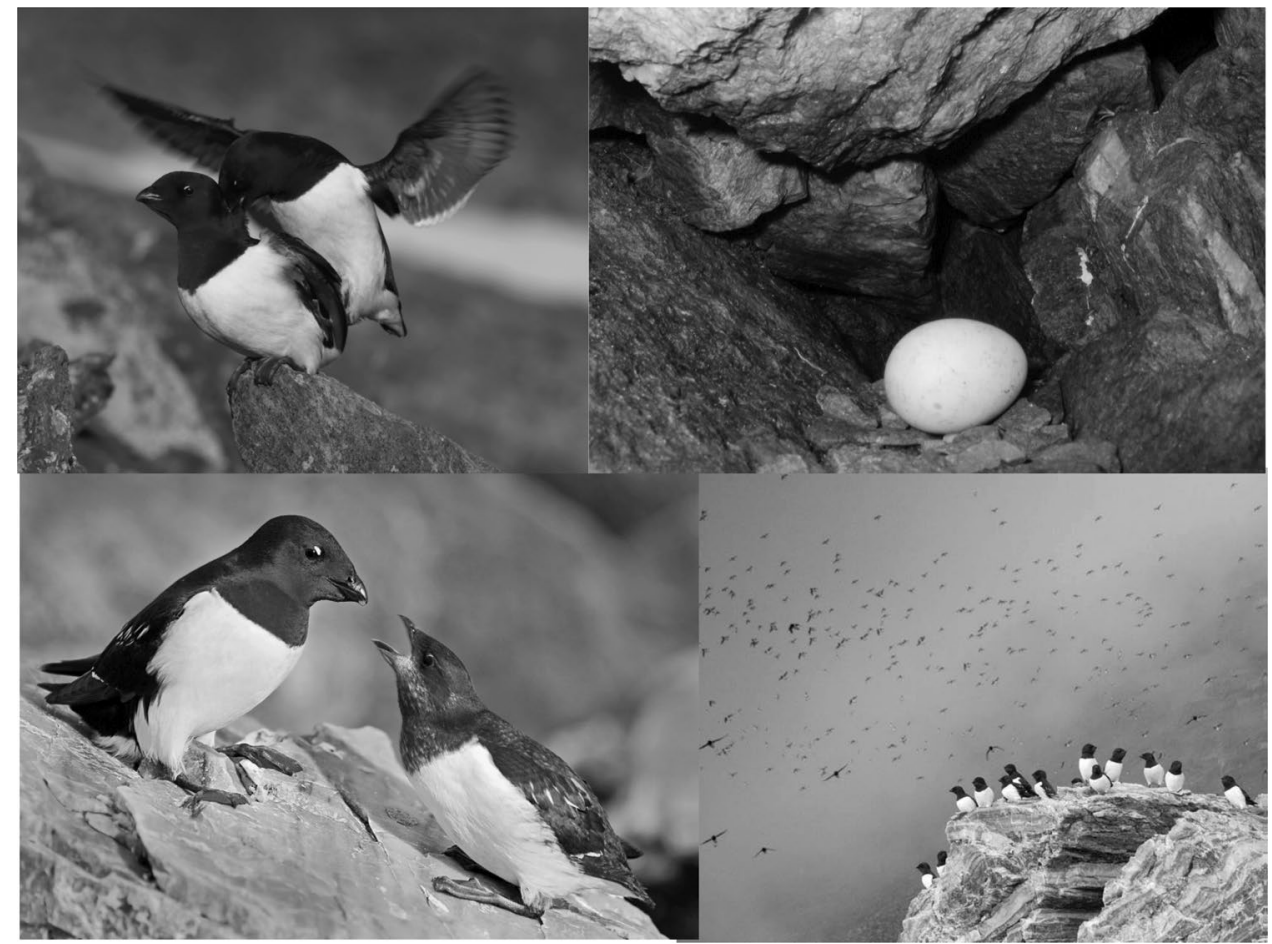

the monitoring of Arctic seabird species by the Conservation of Arctic Flora and Fauna Working Group of the Arctic Council as part of the Circumpolar Biodiversity Monitoring Programme (Irons et al. 2015). Foraging at sea and nesting on land, the Little Auk also plays an important part in transporting organic matter from the marine ecosystem to the nutrient-poor Arctic tundra (Stempniewicz et al. 2007; González-Bergonzoni et al. 2017; Mosbech et al. 2018). This fertilization not only enriches the terrestrial part of the ecosystem, enhancing vegetation and invertebrate communities around Little Auk colonies (Zmudczyńska et al. 2012; Zwolicki et al. 2016a); it also attracts a variety of vertebrates that consume the lush vegetation (Jakubas et al. 2008b; Wojczulanis-Jakubas et al. 2008; Mosbech et al. 2018). From the human perspective, the Little Auk in the Qaanaaq region (Thule, NW Greenland) added resilience to human societies in times when marine mammals were difficult to access because of sea ice conditions and/or after the relevant hunting techniques had been forgotten (Mosbech et al. 2018). Traditional kiviaq is made from whole Little Auk bodies sewn in sealskin bags that ferment for several months (Mosbech et al. 2018).

In the context of the breeding range, population size, diet and its importance for the High Arctic ecosystem, the Little Auk is an excellent model species for studying the response of endemic High Arctic organisms to ongoing climatic and anthropogenic changes, and may act as an ecological indicator of global changes, particularly well-pronounced in the Arctic. Being a seabird, with a high annual adult survival, social and genetic monogamy, bi-parental care and a single-egg clutch (Stempniewicz 2001; Wojczulanis-Jakubas et al. 2009a), the Little Auk also constitutes a perfect model species for studying behavioural and evolutionary ecology, whenever such a system refers to birds with similar characteristics and/or life strategies.

Given the importance of the Little Auk for the functioning of the Arctic ecosystem, as well as the growing interest in polar research, we review here studies on the Little Auk's ecology, stressing their contributions to ecology and beyond. We also point out recent progress and as yet unfulfilled potential for studies focussing on this species and discuss its advantages and disadvantages as an ecological indicator and a model species.

\section{Materials and methods}

We searched the Scopus database for documents (type "article" or "review") using the expressions "little Auk", "dovekie", "Alle alle" or "Plautus alle" in the title, abstract or keywords (accessed 01.11.2021). We found a total of 281 papers published from 1921 to 2021 . We chose studies, the results of which illustrate the role of the Little Auk as an indicator and/or model species, and summarized them in order to highlight the most important features of the species and to provide examples of its usefulness in various types of research. To compare the number of documents about another "iconic" or "charismatic" Arctic species, the Polar 
Bear Ursus maritimus, we also searched the Scopus database for documents (type "article" or "review") using the expressions "polar bear" or "Ursus maritimus" in the title, abstract, or keywords (accessed 01.11.2021). Here, we found 1789 documents published between 1917 and 2022.

\section{Results and discussion}

Being a small pelagic seabird, and breeding in remote Arctic archipelagos (i.e. difficult to access), the Little Auk has long been neglected as a study species. However, rapid globalization and human expansion into the polar regions, as well as the development and miniaturization of various tracking technologies, have greatly reduced the challenge associated with the study of the Little Auk's ecology. The number of documents found in the Scopus database has increased considerably in the last decade (20 in 1921-1989, 38 in 1990-1999, 63 in 2000-2009, 142 in 2010-2019 and 18 in 2020-2021). Obviously, that is far less than what is available for the iconic Polar Bear (184 in 1917-1989, 225 in 1990-1999, 436 in 2000-2009, 793 in 2010-2019 and 151 in 2020-2022). Nonetheless, the Little Auk has recently received much well-deserved research attention, indicating its usefulness as an ecological indicator and model species.

\section{The Little Auk: key life-history facts}

\section{A numerous and exclusively High Arctic breeder}

The breeding range of the Little Auk is circumpolar and limited to High Arctic archipelagos, with the largest colonies extending between $70^{\circ}$ and $80^{\circ} \mathrm{N}$. The breeding population is very hard to estimate because of its habit of nesting in rock crevices in mountain scree. The world population is estimated at 37-40 million pairs (Wojczulanis-Jakubas et al. 2011b; Keslinka et al. 2019), with the largest breeding aggregations in Greenland and on Spitsbergen (Fig. 2). The present abundance of Little Auks is assumed to be the effect of the extermination of the Greenland Whale Balaena

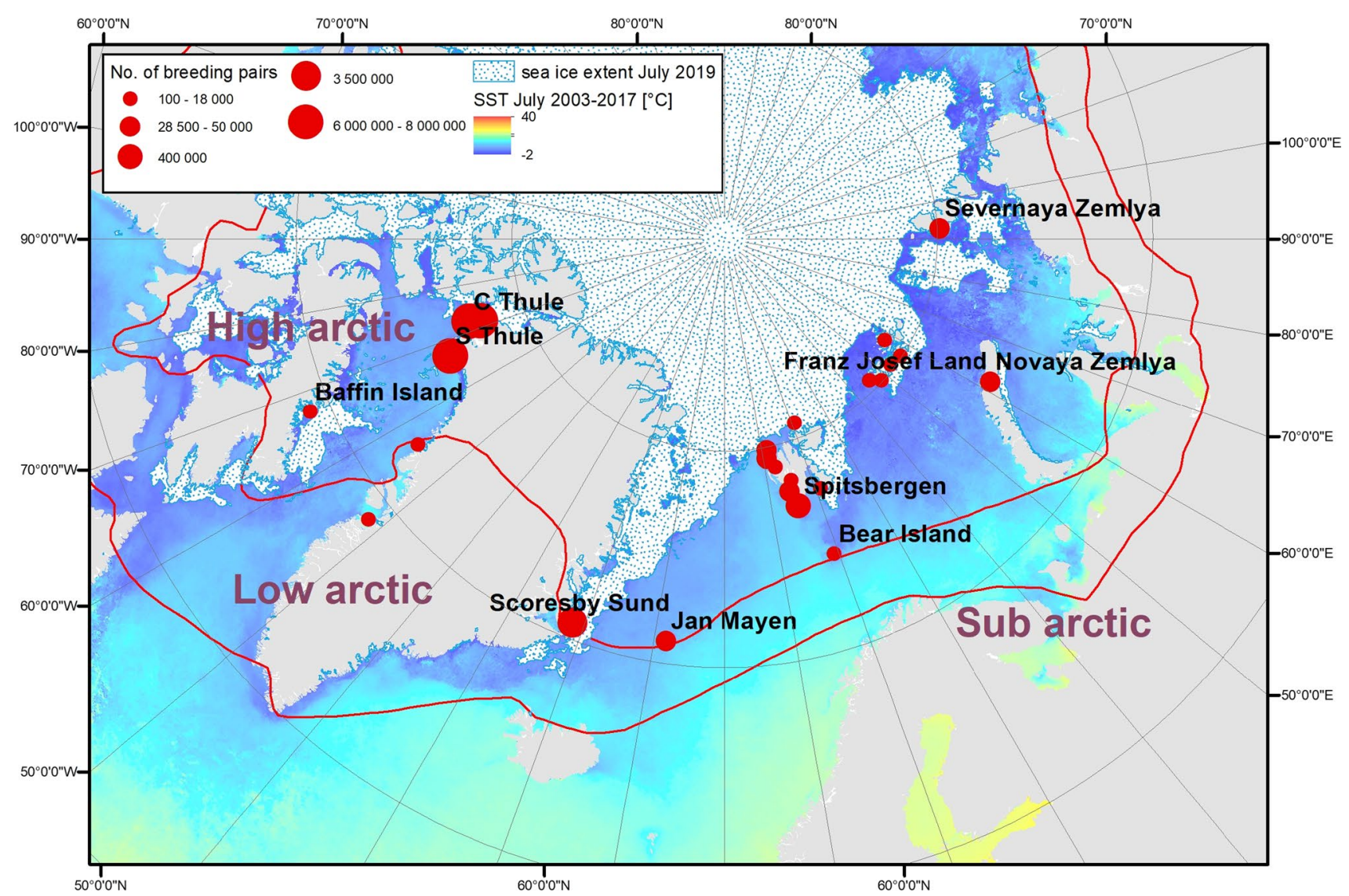

Fig. 2 Breeding distribution of the Little Auk (colonies indicated by red dots) with sea surface temperature (mean for July 2003-2017; source: Moderate-resolution Imaging Spectroradiometer (MODIS) Aqua satellite data from Ocean Color Data webpage, https://ocean data.sci.gsfc.nasa.gov/MODIS-Aqua) and sea ice distribution [July
2009 as an example; source: Multisensor Analysed Sea Ice ExtentNorthern Hemisphere (MASIE-NH), Version 1 with $4 \mathrm{~km}$ grid cell size (National Ice Center (NIC) and NSIDC 2010)]. Location of Arctic zones according to (CAVM Team 2003). Little Auk population estimates after Keslinka et al. (2019) 
mysticetus in Spitsbergen in the seventeenth century, which released a vast amount of zooplankton that would be otherwise have been consumed by those Arctic whales (Wȩsławski et al. 2000).

Wintering quarters have only recently been identified, following the deployment of miniaturized light-based loggers. Results so far indicate that the wintering areas are to some extent specific to particular breeding colonies, but overall are situated in the NW Atlantic, off Newfoundland and SW Greenland, and in the Norwegian and North Seas (Fort et al. 2013; Dufour et al. 2021; SEATRACK project website http://seatrack.seapop.no/map/).

Despite breeding under continuous daylight conditions at high latitudes, the Little Auk at the population level exhibits a daily rhythm of activity in the colony, although particular individuals may become arrhythmic with regard to the 24-h cycle (Stempniewicz 1986; Wojczulanis-Jakubas et al. 2020b).

\section{Morphological variation}

This exists across the worldwide geographical range of the Little Auk (Fig. 2), with a longitudinal increase in body size from west to east. The smallest birds breed in the western part of the population range (Greenland and Jan Mayen), medium-sized individuals in Svalbard and the largest birds (the subspecies A. a. polaris) in the eastern part of the study area, i.e. Franz Josef Land. The trend is negatively correlated with air temperature during the summer; whilst this may be adaptive, more studies are needed in order to draw definitive conclusions (Wojczulanis-Jakubas et al. 2011b).

\section{Weak genetic population differentiation}

Based on the model of isolation by distance, such differentiation has been documented for the Little Auk (Wojczulanis-Jakubas et al. 2014c). Even the two morphologically different Little Auk subspecies are quite similar with respect to both mitochondrial DNA and microsatellite loci (Wojczulanis-Jakubas et al. 2015b). The genetic similarity of the breeding populations across the whole range, including both subspecies, is likely to be an effect of strong gene flow between populations, which may well be facilitated by the overlapping wintering areas of the various breeding populations (SEATRACK project website http://seatrack.seapop. no/map/).

\section{Metabolic rate of the Little Auk}

Corrected for body size, it is the highest of all seabirds studied (Gabrielsen et al. 1991). This is due to the wingpropelled locomotion during diving, and the combination of flapping flight, high wing-loading and long foraging distances (Stempniewicz 1982; Gabrielsen et al. 1991; Konarzewski et al. 1993; Jakubas et al. 2013).

\section{The only exclusively zooplanktivorous seabird in the North Atlantic}

During the breeding season, adult Little Auks supply their chick with energy-rich copepods associated with cold water masses from the genus Calanus, especially $C$. glacialis and C. hyperboreus. Little Auks from colonies that are situated at a cost-effective distance from the marginal ice zone may also forage on the sympagic amphipod Apherusa glacilis (Karnovsky et al. 2010; Kwasniewski et al. 2010; Jakubas et al. 2011; Frandsen et al. 2014; Møller et al. 2018). Adults use the sublingual sack, also called the gular pouch, to deliver food to the chick (Fig. 1; useful for identifying dietary components as the prey items are still fresh). Whilst foraging under water, Little Auks capture copepods by visually guided suction feeding, achieved through an extension of their gular pouch (Enstipp et al. 2018). Thus, the highest densities of foraging Little Auks in the vicinity of one of the largest breeding aggregations in Svalbard were observed in areas with abundant $C$. glacialis and high water transparency (Stempniewicz et al. 2013, 2021). The maximum depth (mean $\pm \mathrm{SD}$ ) recorded during foraging dives by Little Auks from colonies on Spitsbergen and on Greenland was $9.9 \pm 6.9 \mathrm{~m}$, whilst the maximum depth attained by any bird was $37.8 \mathrm{~m}$ (Karnovsky et al. 2011). The diet of adults is less well known, but the similar $\delta^{15} \mathrm{~N}$ isotopic values in chick and adult blood samples strongly suggest that adult and young Little Auks feed on similar prey (Fort et al. 2010). The diet of the Little Auk during the non-breeding period is not known for certain, but existing studies indicate that it probably consists mostly of krill, amphipods and small fish (Rosing-Asvid et al. 2013).

\section{The Little Auk as an ecological indicator of global changes}

\section{Indicator of environmental changes}

The Arctic is undergoing dramatic climate changes, recently called Arctic borealization (Box et al. 2019) or Atlantification, which are transforming this unique polar ecosystem in certain areas of the Arctic into an average North Atlantic ecosystem (Csapó et al. 2021; Descamps and Strøm 2021). This is affecting a great many marine and terrestrial organisms adapted to the conditions hitherto specific to polar regions (Wassmann et al. 2011; Descamps et al. 2017). There is thus an urgent need for research on the fate of species emblematic of the Arctic. In the light of the fact that its breeding range is restricted to the High Arctic, its food preferences during the breeding period (energy rich zooplankton 
associated with cold water masses) and high energy requirements, the Little Auk is regularly studied in the context of avian responses to environmental variability. Some Little Auk responses to environmental variability serve as 'footprints' of climate change [sensu (Wassmann et al. 2011), i.e. referring to documented changes in the range, community structure, abundance, phenology, behaviour, growth or condition of marine organisms in the Arctic consistent with or apparently in response to current climate change]. The footprints documented for Little Auks include changes in dietary composition, reproductive output, adult survival and phenology; they are summarized below.

A multiyear (2001-2008) study on oceanographic conditions and the zooplankton community in the foraging area of Little Auks from a colony on Spitsbergen has demonstrated that food quality and quantity varies greatly amongst years, but within a range that still allows parental birds to provide chicks with lipid-rich Arctic copepods (Kwasniewski et al. 2012). To some extent, Little Auks are capable of buffering suboptimal environmental and food conditions. Even where and when the preferred Arctic zooplankton is less abundant, they have been able to breed successfully with no negative consequences on chick survival, stress levels, or the body masses of adults and chicks (Kwasniewski et al. 2010; Jakubas et al. 2011, 2017; Grémillet et al. 2012). However, some studies have reported serious consequences of suboptimal foraging conditions-a slower chick growth rate (Jakubas et al. 2013, 2020; Kidawa et al. 2015), a decrease in interannual survival rates of adult Little Auks (Hovinen et al. 2014a) with a potentially strong effect on population dynamics and viability in such a long-lived species (Sæther and Bakke 2000). It has been found that interannual changes in sea ice phenology and primary productivity pulses (affecting the transfer of biomass and energy through Arctic food webs) in Svalbard affected the breeding performance of Little Auks: chick survival decreased with the increasing time lag between the annual peaks of sea ice extent and primary production (Ramírez et al. 2017). In the E Greenland population, adult body condition and chick growth rate were negatively linked to sea ice concentration and mercury contamination (Amélineau et al. 2019). All these factors indicate that despite the apparent flexibility of Little Auks as regards foraging (Jakubas et al. 2011, 2017; Grémillet et al. 2012; Amélineau et al. 2016b), deteriorating oceanographic conditions pose a threat to the population of this abundant endemic Arctic seabird. Little Auk populations from Iceland and S Greenland, breeding at the species' southernmost range margin, collapsed following the nineteenth century shift in sea currents and plankton dispersal and harvest (Stempniewicz 2001; Jakubas et al. 2022). Models of future foraging habitat suitability assuming scenarios of $1{ }^{\circ} \mathrm{C}$ and $2{ }^{\circ} \mathrm{C} \mathrm{SST}$ increases and the lack of sea ice, have predicted losses of suitable foraging habitat for the majority of
Little Auk colonies in Svalbard (Jakubas et al. 2017). Thus, over longer time scales, the negative consequences of global warming on the Little Auk population appear inevitable.

Little Auks have also been reported to react to changes in air temperature in terrestrial ecosystems. For a colony on Spitsbergen, the median hatching date became 4.5 days earlier over 1963-2008 in response to the increase in spring air temperatures $\left(0.9{ }^{\circ} \mathrm{C}\right.$ per decade). Little Auks occupy nest chambers within the rock debris as soon as the snow cover has melted sufficiently to allow access to them. Therefore, the timing of egg-laying appears to be strongly determined by air temperature affecting snow melt in the colony (Moe et al. 2009).

\section{Indicator of environmental contamination}

The Little Auk may also serve as a good model for studying the bioaccumulation and biomagnification of toxic elements (e.g. mercury, Hg). Being a top predator in the marine Arctic environment, the Little Auk can be a true sentinel of anthropogenic influence in this region. It moults twice a year, with different feather types being grown at different times of the year and locations (breeding/non-breeding grounds), which allows investigation of the exposure of Little Auks to elements throughout the annual cycle (Fort et al. 2013). Recent studies have revealed spatial and temporal variations in $\mathrm{Hg}$ concentrations in Little Auks, indicating greater exposure during the non-breeding period in the wintering areas than during the breeding season (Renedo et al. 2020; PacynaKuchta et al. 2020; Albert et al. 2021). Although for now, overall $\mathrm{Hg}$ concentrations in Little Auks are relatively low compared to other Arctic seabirds (Albert et al. 2021), females with high $\mathrm{Hg}$ levels tend to lay smaller eggs (Fort et al. 2014). It remains to be explored whether smaller eggs are related to poorer breeding success, or whether there are other negative consequences of $\mathrm{Hg}$ contamination, but the few existing studies clearly show that even species living in supposedly pristine environments, such as the Little Auk, are not free of contaminants. Recent studies have revealed microplastics in Little Auks (Amélineau et al. 2016a; AveryGomm et al. 2016); although overall the number and mass of plastics ingested was small, these may be increasing. Arctic seabirds thus continue to face threats from a rapidly changing marine environment (Fife et al. 2015; Avery-Gomm et al. 2016).

\section{Population size monitoring}

Because of the difficulties in estimating the population size of this species, breeding as it does in large aggregations in remote areas on stony slopes, the few reliable counts of local population size are based on indirect methods (aerial images of a colony, extrapolation of densities from 
small patches of a colony, the proportion of resightings of marked birds in a study plot followed by comparisons with the number of unmarked birds observed in the plot) (Evans 1981; Stempniewicz 1981; Isaksen and Bakken 1995; Kampp et al. 2000; Mosbech et al. 2017; Keslinka et al. 2019). Since Little Auks are vulnerable to the consequences of climate warming, not to mention additional threats from oil-drilling activities in the sub-Arctic and Arctic zone, the expansion of shipping routes and the long-distance transport of contaminants (Fort et al. 2013), monitoring of the Little Auk's population trends has been recommended by the Conservation of Arctic Flora and Fauna and Protection of the Arctic Marine Environment working group of the Arctic Council (Irons et al. 2015). Establishing integrated monitoring programmes of Little Auks, amongst the most numerous High Arctic seabirds, is crucial in order to support adaptive management in the rapidly changing High Arctic environment.

\section{The Little Auk as a model species in ecological studies}

\section{Mate choice}

Given its modest ornamentation and negligible sexual dimorphism (Jakubas and Wojczulanis 2007), the Little Auk may not be a prime species for studying mate choice as regards sexually selected traits. However, male and female Little Auks do differ in a few traits (morphological, biometrical, hormonal and behavioural), and that makes the species an interesting model for examining the question of mate choice. This is especially relevant in the context of other Little Auk characteristics, like genetic monogamy (Wojczulanis-Jakubas et al. 2009a), high partner fidelity (Wojczulanis-Jakubas et al. 2020a) and extensive, coordinated parental care (Harding et al. 2004; WojczulanisJakubas et al. 2018a); these are all closely related to the choice of breeding partner. An assortative mating pattern has been found in the Little Auk in both fixed and labile traits. Assortative mating with respect to wing length may be a reflection of their migration patterns. As migration distance can be heritable, a positive correlation between pair members with regard to such a trait could prevent the production of offspring that would have a non-adaptive mixture of migration distance programmes resulting in an unclear migration area (Wojczulanis-Jakubas et al. 2018b). The significant and positive correlation between pair members that has been reported in hormonal stress response may also be adaptive. If conditions in foraging areas are unfavourable, both parents need to increase their efforts in a coordinated manner to ensure that a given breeding attempt is successful (Wojczulanis-Jakubas et al. 2018b).

\section{Parental care}

The long and extensive bi-parental care (1 month of incubation +1 month of chick rearing, possibly post-fledging care), required to raise the single chick successfully (Stempniewicz 2001), creates an excellent reproductive system in which to examine the cause and effect of sexual differences in parental efforts (Wojczulanis et al. 2006; Wojczulanis-Jakubas et al. 2012, 2014a, 2015a). This topic has long been explored with regard to sexual conflict, including some Little Auk studies, e.g. (Wojczulanis-Jakubas et al. 2012). Currently, parental care is being intensively studied in the context of cooperation between the breeding partners (Griffith 2019; Wojczulanis-Jakubas 2021), where the Little Auk has been found to be a particularly useful model species (Wojczulanis-Jakubas et al. 2018a). Recent results have demonstrated that Little Auk parents not only both provide food for their chick at an equal rate, but also coordinate their foraging trips so as to minimize the time between feedings (Wojczulanis-Jakubas et al. 2018a; Grissot et al. 2019).

Despite the similar contributions made by male and female Little Auks to parental care for most of the breeding season, it is the males that take over all parental duties at the end of the nesting period, when females desert the colony (Harding et al. 2004; Wojczulanis-Jakubas and Jakubas 2012). As paternal care resulting from brood desertion by the female is rather unusual in monogamous birds [if only one sex deserts, it is more likely to be the male (Wojczulanis-Jakubas et al. 2020a)], the Little Auk system provides a quite unique perspective within which to fully understand the evolution and adaptive value of such behaviour in birds. This is especially true, given that none of several hypotheses proposed to explain this aspect of female behaviour [i.e. (1) decline in female body condition as the breeding season progresses because of higher primary reproductive investments, (2) remating with a new partner, (3) male aptitude for escorting the fledgling to sea, (4) reduced winter survival after the breeding season], seem to be fully applicable to the Little Auk (Wojczulanis-Jakubas et al. 2009b, 2012; Wojczulanis-Jakubas and Jakubas 2012; Jakubas and Wojczulanis-Jakubas 2013; Wojczulanis-Jakubas et al. 2013, 2014a, b, 2015a, 2018c, 2020a).

The single-egg/chick raised by the Little Auk in a hidden nest chamber also creates an excellent study system for parent-offspring recognition and communication. First, this simple configuration greatly facilitates the investigation of signal transmission between the partners. Second, it provides a control case for other systems with multiple individuals in the brood. Given the single chick in the brood and its 
"fixed" position in the nest, Little Auk parents theoretically do not need a signal to recognize their offspring. Since the costs of foraging are considerable (Gabrielsen et al. 1991; Konarzewski et al. 1993), parent birds should also be resistant to chick begging, so potentially, the evolution of parent-offspring communication could be constrained. Nevertheless, Little Auk parents do communicate with their chicks acoustically (Kidawa et al. 2017), and potentially in other ways, too. The contrasting expectation and results create an intriguing background for examining the issue of parent-offspring communication.

\section{Predator-prey interaction}

The Little Auk is a very attractive subject for predator-prey interaction studies, which are usually extremely difficult to perform owing to the complexity of predator and prey behaviour and the minimal likelihood of observing such episodes. Such studies in Arctic conditions may be highly effective because of the easy accessibility and observation of an unlimited number of sequences of events. The most important predators of Little Auks are the Arctic Fox Vulpes lagopus and Glaucous Gull Larus hyperboreus (Stempniewicz 1995). Predators have adopted various techniques for hunting Little Auks efficiently (Stempniewicz 1983, 1993; Jakubas and Wojczulanis-Jakubas 2010). Anti-predatory adaptations in Little Auks function at the individual, population and species levels. As a result, predatory pressure from Glaucous Gulls is strictly limited by time mechanisms. They include the synchronization of all stages of the breeding period, most strongly expressed at fledging when the chick is easy prey. Departure from the nest is condensed into a few days and several hours a day, resulting in a swamping effect, which, together with the protective behaviour of the father, substantially minimizes losses (Stempniewicz 1995; Wojczulanis et al. 2005).

\section{Foraging ecology}

The Little Auk is one of the few pelagic seabirds (apart from Procellariiformes and Sphenisciformes), and so far the only alcid species, reported to exhibit a bi-modal foraging strategy during the chick-rearing period, i.e. alternating long foraging trips (both in terms of time and distance) with a series of short ones (Steen et al. 2007; Welcker et al. 2009a; Wojczulanis-Jakubas et al. 2010a; Jakubas et al. 2012). Diving behaviour generally differs between the long and short foraging trips with the magnitude of the disparity in diving characteristics depending on local foraging conditions (Karnovsky et al. 2011; Brown et al. 2012). This dual foraging strategy is interesting in the context of parental investment, as it is assumed to have evolved to reconcile the conflicting interests of parents and offspring (Jakubas et al. 2014). A study of body mass changes in Little Auk adults returning to their nests from foraging flights revealed that during short trips, the birds collect food for the chicks whereas the long trips are dedicated mainly to self-maintenance (Welcker et al. 2012). Moreover, with the two parents feeding the chick and both exhibiting the dual foraging strategy, the Little Auk is a perfect model species for examining parental coordination of the feeding performance. Studies show that parenting males and females avoid overlapping their long foraging trips, i.e. coordinate their foraging flights, thereby ensuring regular provisioning of the chick (Wojczulanis-Jakubas et al. 2018a; Grissot et al. 2019).

\section{Ecosystem engineering}

Apart from the effects of high numbers of individuals breeding in particular colonies, Little Auks profoundly alter terrestrial Arctic ecosystems by supplying marinederived nutrients (MDN) (Skrzypek et al. 2015; Zwolicki et al. 2016a, b; González-Bergonzoni et al. 2017). Such nitrogen-rich 'oases' underlying Little Auk colonies massively enhance primary production, resulting in a higher richness of plant cover, which attracts herbivores, including geese, Reindeer Rangifer tarandus, Muskoxen Ovibus moschatus and some invertebrates (Stempniewicz et al. 2007; Mosbech et al. 2018). The large Little Auk colonies around the North Water Polynya in Greenland have profoundly altered the adjacent freshwater and terrestrial ecosystems. It has been estimated that MDN fuels more than $85 \%$ of terrestrial and aquatic biomass in bird influenced systems [this subsidy is much higher than that reported for migrating Pacific salmon species-23-25\% of the biomass in aquatic organisms and terrestrial vegetation (González-Bergonzoni et al. 2017)]. A study performed in the large Little Auk colony on Spitsbergen found that the birds, respectively, supply the colony and the tundra beneath with 60 and 25 tons per $\mathrm{km}^{2}$ of excreta (dry mass) annually (Stempniewicz 1990), and that the percentage of the total tundra nitrogen pool provided by birds ranged from 0 to $21 \%$ in patterned-ground tundra to $100 \%$ in ornithocoprophilous tundra (Skrzypek et al. 2015). Large colonies of Little Auks are usually located on gently sloping mountains, as a rule a few kilometres from the seashore, whereas colonies of piscivorous seabirds are situated on rocky coastal cliffs. The impact of the latter group on terrestrial ecosystems is therefore much smaller compared to Little Auks because the guano deposited on the seabird cliffs is rapidly washed out to sea (Stempniewicz et al. 2007). These results clearly indicate that the Little Auk 


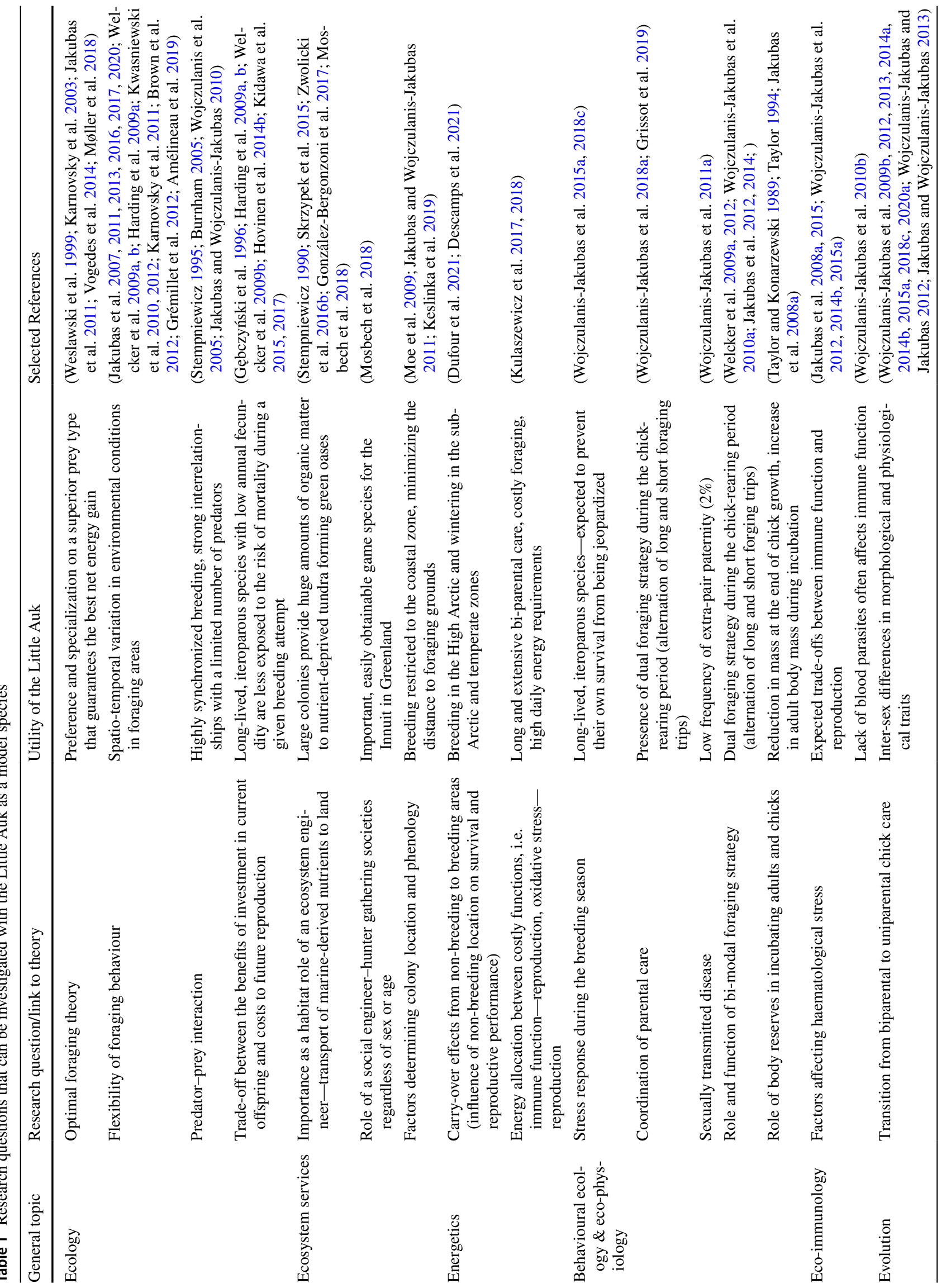


acts as an ecosystem engineer, transforming terrestrial ecosystems right across its breeding range. Hence, ongoing climate change, causing a deterioration of Little Auk feeding conditions, may force them to leave their current breeding areas, which will have broad implications for both the marine and terrestrial Arctic ecosystems (Stempniewicz et al. 2007).

\section{Concluding remarks}

Given their characteristics (highly visible, easy to observe and capture in their colonies, allowing measurements of a wide variety of variables), seabirds have frequently been identified as useful indicators of the health and status of marine ecosystems, since they act as sentinels or bio-monitors of ecosystem change (e.g. contaminant load indicates pollution) and/or as quantitative indicators of specific ecosystem components, such as prey abundance (Piatt et al. 2007). In this context, the Little Auk, with all its life-history traits, breeding exclusively in the High Arctic, which is warming up more rapidly than any other region on Earth, has the potential for being both a qualitative and a quantitative ecological indicator of global changes, and a model species for other seabirds. It also fulfils many criteria applied to the selection of organisms for biological research (Dietrich et al. 2020): easy physical access (large breeding colonies are relatively easy to get to), phenomenal access (i.e. relevant to specific research questions concerning particular aspects of interest, e.g. the transition from bi-parental to uni-parental care), viability (a long-lived bird) and previous studies (knowledge about the species is already available). As in the case of each monitoring or model species, there are specific pros and cons for using the Little Auk in various studies (Tables 1 and 2). Some features of the species (a single-egg clutch/one chick, zooplanktivorous diet, High Arctic breeding range) are hard to extrapolate to other systems, but these features also greatly simplify research on questions that remain challenging in more complex systems, as well as offering an exceptional perspective, rarely considered in ecological studies. There are still many important issues to be investigated with the Little Auk as the model species. They include the mechanisms by which attractive foraging areas are detected, the threshold of environmental conditions above which birds are no longer able to compensate for suboptimal foraging conditions, the physiological consequences of rising air temperatures during the breeding season in High Arctic species, the reasons for the transition from bi-parental to uniparental care and the mechanisms by which parents coordinate their efforts/duties. The results of studies focussed on these issues have the potential to be extrapolated to other groups of organisms. 
Table 2 Pros and cons of the Little Auk as a model species with regard to its specific features

\begin{tabular}{|c|c|c|}
\hline Feature & Pros & Cons \\
\hline Colonial breeding & Easily accessible, good sample size & Population size not easy to estimate \\
\hline Nesting in scree & Relatively safe from nest predation & $\begin{array}{l}\text { Access to nests difficult, problem with GPS } \\
\text { signal detection for GPS logger }\end{array}$ \\
\hline Breeding in the High Arctic & $\begin{array}{l}\text { Good model for studying polar endothermic } \\
\text { organisms }\end{array}$ & $\begin{array}{l}\text { Fieldwork in remote areas in harsh conditions, } \\
\text { fieldwork logistics often complicated }\end{array}$ \\
\hline Zooplanktivorous diet & $\begin{array}{l}\text { Good indicator of changes in zooplankton } \\
\text { communities }\end{array}$ & $\begin{array}{l}\text { Number of zooplanktivorous seabirds in the } \\
\text { northern Atlantic too low to generalize results }\end{array}$ \\
\hline Food delivered in gular pouch & $\begin{array}{l}\text { Fresh prey items easy to collect in a relatively } \\
\text { non-invasive way and easy to identify (not } \\
\text { digested) }\end{array}$ & - \\
\hline One egg/chick annually & Lack of within-brood competition & $\begin{array}{l}\text { Lack of partial brood reduction in response to } \\
\text { adverse conditions-this acts as a binomial } \\
\text { indicator (breeding success } 0 / 1 \text { ) reacting to } \\
\text { environmental changes after crossing a critical } \\
\text { threshold }\end{array}$ \\
\hline Small body size & Relatively easy handling & $\begin{array}{l}\text { Limitation in size of devices deployed (TDR, } \\
\text { GPS-loggers) }\end{array}$ \\
\hline Pelagic life style & Good indicator of ocean health & $\begin{array}{l}\text { Accessible on land only during the breeding } \\
\text { season }\end{array}$ \\
\hline $\begin{array}{l}\text { Transition from bi-parental to uni-parental } \\
\text { chick care }\end{array}$ & Good species to study this phenomenon & $\begin{array}{l}\text { Results cannot be extrapolated to species with a } \\
\text { uniform type of parental care throughout the } \\
\text { chick-rearing period }\end{array}$ \\
\hline $\begin{array}{l}\text { Biparental care with similar male and female } \\
\text { contributions throughout the majority of the } \\
\text { breeding season }\end{array}$ & $\begin{array}{l}\text { Simplified reproductive system, especially for } \\
\text { studying parental coordination }\end{array}$ & $\begin{array}{l}\text { Conclusions not always applicable to other } \\
\text { species }\end{array}$ \\
\hline Lack of blood parasites & $\begin{array}{l}\text { Lack of confounding effects affecting immune } \\
\text { function/health status }\end{array}$ & - \\
\hline
\end{tabular}

Acknowledgements We thank Yuki Brooks for her encouragement and support in preparing the manuscript and clarifying the story. We thank Iain Stenhouse and two anonymous reviewers for their constructive and helpful comments. We appreciate the improvements in English usage made by Peter Senn.

Author contributions KWJ Conceptualization (lead); Visualization (lead); Writing_original draft (lead); Writing_review and editing (equal). DJ Conceptualization (lead); Investigation (lead); Methodology (lead); Visualization (lead); Writing — original draft (lead); Writing-review and editing (equal). LS Conceptualization (lead); Writing-original draft (supporting); Writing—review and editing (equal).

Funding The most recent results on parental coordination described in the manuscripts were supported by grants from Poland through the Polish Ministry of Science and Education (2017/25/B/NZ8/01417 to KWJ).

Data availability Not relevant.

Code availability Not relevant.

\section{Declarations}

Conflict of interest The authors declare neither conflicts of interest nor competing interests.
Open Access This article is licensed under a Creative Commons Attribution 4.0 International License, which permits use, sharing, adaptation, distribution and reproduction in any medium or format, as long as you give appropriate credit to the original author(s) and the source, provide a link to the Creative Commons licence, and indicate if changes were made. The images or other third party material in this article are included in the article's Creative Commons licence, unless indicated otherwise in a credit line to the material. If material is not included in the article's Creative Commons licence and your intended use is not permitted by statutory regulation or exceeds the permitted use, you will need to obtain permission directly from the copyright holder. To view a copy of this licence, visit http://creativecommons.org/licenses/by/4.0/.

\section{References}

Albert C, Helgason HH, Brault-Favrou M et al (2021) Seasonal variation of mercury contamination in Arctic seabirds: a pan-Arctic assessment. Sci Total Environ 750:142201. https://doi.org/10. 1016/j.scitotenv.2020.142201

Amélineau F, Bonnet D, Heitz O et al (2016a) Microplastic pollution in the Greenland Sea: background levels and selective contamination of planktivorous diving seabirds. Environ Pollut 219:11311139. https://doi.org/10.1016/j.envpol.2016.09.017

Amélineau F, Grémillet D, Bonnet D et al (2016b) Where to forage in the absence of sea ice? Bathymetry as a key factor for an Arctic 
Seabird. PLoS ONE 11:e0157764. https://doi.org/10.1371/journ al.pone. 0157764

Amélineau F, Grémillet D, Harding AMA et al (2019) Arctic climate change and pollution impact little auk foraging and fitness across a decade. Sci Rep 9:1014. https://doi.org/10.1038/ s41598-018-38042-Z

Avery-Gomm S, Valliant M, Schacter CR et al (2016) A study of wrecked Dovekies (Alle alle) in the western North Atlantic highlights the importance of using standardized methods to quantify plastic ingestion. Mar Pollut Bull. https://doi.org/10.1016/j. marpolbul.2016.08.062

Box JE, Colgan WT, Christensen TR et al (2019) Key indicators of Arctic climate change: 1971-2017. Environ Res Lett 14:045010

Brown ZW, Welcker J, Harding AMA et al (2012) Divergent diving behavior during short and long trips of a bimodal forager, the little auk Alle alle. J Avian Biol 43:215-226. https://doi.org/10. 1111/j.1600-048X.2012.05484.X

Burnham KK (2005) Dovekie response to Glaucous Gull behaviour and approach in North Greenland. Dansk Orn Foren Tidsskr 99:115-118

CAVM Team (2003) Circumpolar Arctic Vegetation Map. Conservation of Arctic Flora and Fauna (CAFF) Map No. 1.U.S. Fish and Wildlife Service, Anchorage, Alaska

Clairbaux M, Fort J, Mathewson P et al (2019) Climate change could overturn bird migration: transarctic flights and high-latitude residency in a sea ice free Arctic. Sci Rep 9:1-13. https://doi.org/10. 1038/s41598-019-54228-5

Csapó HK, Grabowski M, Węsławski JM (2021) Coming homeBoreal ecosystem claims Atlantic sector of the Arctic. Sci Total Environ 771:144817. https://doi.org/10.1016/j.scitotenv.2020. 144817

Descamps S, Strøm H (2021) As the Arctic becomes boreal: ongoing shifts in a high-Arctic seabird community. Ecology. https://doi. org/10.1002/ECY.3485

Descamps S, Aars J, Fuglei E et al (2017) Climate change impacts on wildlife in a High Arctic archipelago-Svalbard, Norway. Glob Chang Biol 23:490-502. https://doi.org/10.1111/gcb.13381

Descamps S, Merkel B, Strøm H et al (2021) Sharing wintering grounds does not synchronize annual survival in a high Arctic seabird, the little auk. Mar Ecol Prog Ser 676:233-242. https:// doi.org/10.3354/meps 13400

Dietrich MR, Ankeny RA, Crowe N et al (2020) How to choose your research organism. Stud Hist Philos Sci Part C Stud Hist Philos Biol Biomed Sci 80:101227. https://doi.org/10.1016/j. shpsc.2019.101227

Dufour P, Wojczulanis-Jakubas K, Lavergne S et al (2021) A twofold increase in migration distance does not have breeding consequences in a long-distance migratory seabird with high flight costs. Mar Ecol Prog Ser 676:117-126. https://doi.org/ $10.3354 /$ meps 13535

Enstipp MR, Descamps S, Fort J, Grémillet D (2018) Almost like a whale-first evidence of suction feeding in a seabird. J Exp Biol. https://doi.org/10.1242/jeb.182170

Evans PGH (1981) Ecology and behaviour of the Little Auk Alle alle in west Greenland. Ibis (Lond 1859) 123:1-18

Fife DT, Robertson GJ, Shutler D et al (2015) Trace elements and ingested plastic debris in wintering dovekies (Alle alle). Mar Pollut Bull 91:368-371. https://doi.org/10.1016/j.marpolbul. 2014.11.029

Fort J, Cherel Y, Harding AMAMA et al (2010) Geographic and seasonal variability in the isotopic niche of little auks. Mar Ecol Prog Ser 414:293-302. https://doi.org/10.3354/meps08721

Fort J, Moe B, Strøm H et al (2013) Multicolony tracking reveals potential threats to little auks wintering in the North Atlantic from marine pollution and shrinking sea ice cover. Divers Distrib 19:1322-1332. https://doi.org/10.1111/ddi.12105
Fort J, Robertson GJ, Grémillet D et al (2014) Spatial ecotoxicology: migratory Arctic seabirds are exposed to mercury contamination while overwintering in the Northwest Atlantic. Environ Sci Technol 48:11560-11567. https://doi.org/10.1021/es504 $045 \mathrm{~g}$

Frandsen MS, Fort J, Rigét FF et al (2014) Composition of chick meals from one of the main little auk (Alle alle) breeding colonies in Northwest Greenland. Polar Biol 37:1055-1060. https://doi.org/ 10.1007/s00300-014-1491-0

Gabrielsen GW, Taylor JRE, Konarzewski M, Mehlum F (1991) Field and laboratory metabolism and thermoregulation in Dovekies (Alle alle). Auk 108:71-78

Gauthier G, Berteaux D, Bty J et al (2011) The tundra food web of Bylot Island in a changing climate and the role of exchanges between ecosystems. Ecoscience 18:223-235. https://doi.org/10. 2980/18-3-3453

Gębczyński A, Taylor JRE, Konarzewski M (1996) Growth of Dovekie (Alle alle) chicks under conditions of increased food demand at the nest: two field experiments. Can J Zool 74:1076-1083. https://doi.org/10.1139/z96-119

González-Bergonzoni I, Johansen KL, Mosbech A et al (2017) Small birds, big effects: the little auk (Alle alle) transforms high arctic ecosystems. Proc R Soc B Biol Sci 284:20162572. https://doi. org/10.1098/rspb.2016.2572

Grémillet D, Welcker J, Karnovsky NJ et al (2012) Little auks buffer the impact of current Arctic climate change. Mar Ecol Prog Ser 454:197-206. https://doi.org/10.3354/meps09590

Griffith SC (2019) Cooperation and coordination in socially Monogamous birds: moving away from a focus on sexual conflict. Front Ecol Evol 7:455. https://doi.org/10.3389/FEVO.2019.00455/ BIBTEX

Grissot A, Araya-Salas M, Jakubas D et al (2019) Parental coordination of chick provisioning in a Planktivorous Arctic seabird under divergent conditions on foraging grounds. Front Ecol Evol 7:349. https://doi.org/10.3389/fevo.2019.00349

Harding AMA, Van Pelt TI, Lifjeld JT, Mehlum F (2004) Sex differences in Little Auk Alle alle parental care: transition from biparental to paternal-only care. Ibis (Lond 1859) 146:642-651. https://doi.org/10.1111/j.1474-919x.2004.00297.x

Harding AMA, Kitaysky AS, Hall ME et al (2009a) Flexibility in the parental effort of an Arctic-breeding seabird. Funct Ecol 23:348358. https://doi.org/10.1111/j.1365-2435.2008.01488.x

Harding AMA, Kitaysky AS, Hamer KC et al (2009b) Impacts of experimentally increased foraging effort on the family: offspring sex matters. Anim Behav 78:321-328. https://doi.org/10.1016/j. anbehav.2009.05.009

Holland MM, Bitz CM, Eby M, Weaver AJ (2001) The role of iceocean interactions in the variability of the North Atlantic thermohaline circulation. J Clim 14:656-675. https://doi.org/10.1175/ 1520-0442(2001)014\%3c0656:TROIOI\%3e2.0.CO;2

Hovinen JEH, Welcker J, Descamps S et al (2014a) Climate warming decreases the survival of the little auk (Alle alle), a high Arctic avian predator. Ecol Evol 4:3127-3138. https://doi.org/10.1002/ ece 3.1160

Hovinen JEH, Wojczulanis-Jakubas K, Jakubas D et al (2014b) Fledging success of little auks in the high Arctic: do provisioning rates and the quality of foraging grounds matter? Polar Biol 37:665674. https://doi.org/10.1007/s00300-014-1466-1

IPCC (2019) IPCC Special Report on the Ocean and Cryosphere in a Changing Climate. IPCC, Geneva, pp 1-765

Irons D, Petersen A, Anker-Nilssen T et al (2015) Circumpolar Seabird monitoring plan. CAFF Monitoring Report No.17

Isaksen K, Bakken V (1995) Seabird Populations in the Northern Barents Sea. Source Data for the Impact Assessment of the Effects of Oil Drilling Activity. Oslo 
Jakubas D, Wojczulanis K (2007) Predicting the sex of Dovekies by discriminant analysis. Waterbirds 30:92-96. https://doi.org/10. 1675/1524-4695(2007)030[0092:PTSODB]2.0.CO;2

Jakubas D, Wojczulanis-Jakubas K (2010) Glaucous gull predation on dovekies: three new hunting methods. Arctic 63:468-470

Jakubas D, Wojczulanis-Jakubas K (2011) Subcolony variation in phenology and breeding parameters in little auk Alle alle. Polar Biol 34:31-39. https://doi.org/10.1007/s00300-010-0856-2

Jakubas D, Wojczulanis-Jakubas K (2013) Rates and consequences of relaying in little auks Alle alle breeding in the High Arctic an experimental study with egg removal. J Avian Biol 44:6268. https://doi.org/10.1111/j.1600-048X.2012.05790.x

Jakubas D, Wojczulanis-Jakubas K, Walkusz W (2007) Response of Dovekie to changes in food availability. Waterbirds 30:421428. https://doi.org/10.1675/1524-4695(2007)030[0421:rodtci] 2.0.co;2

Jakubas D, Wojczulanis-Jakubas K, Kreft R (2008a) Sex differences in body condition and hematological parameters in Little Auk Alle alleduring the incubation period. Ornis Fenn 85:90-97

Jakubas D, Zmudczyńska K, Wojczulanis-Jakubas K, Stempniewicz L (2008b) Faeces deposition and numbers of vertebrate herbivores in the vicinity of planktivorous and piscivorous seabird colonies in Hornsund, Spitsbergen. Polish Polar Res 29:45-58

Jakubas D, Głuchowska M, Wojczulanis-Jakubas K et al (2011) Foraging effort does not influence body condition and stress level in little auks. Mar Ecol Prog Ser 432:277-290. https://doi.org/10. 3354/meps09082

Jakubas D, Iliszko L, Wojczulanis-Jakubas K, Stempniewicz L (2012) Foraging by little auks in the distant marginal sea ice zone during the chick-rearing period. Polar Biol 35:73-81. https://doi.org/10. 1007/s00300-011-1034-x

Jakubas D, Trudnowska E, Wojczulanis-Jakubas K et al (2013) Foraging closer to the colony leads to faster growth in little auks. Mar Ecol Prog Ser 489:263-278. https://doi.org/10.3354/meps 10414

Jakubas D, Wojczulanis-Jakubas K, Iliszko L et al (2014) Foraging strategy of the little auk Alle alle throughout breeding seasonswitch from unimodal to bimodal pattern. J Avian Biol 45:551560. https://doi.org/10.1111/jav.00303

Jakubas D, Wojczulanis-Jakubas K, Kośmicka A (2015) Factors affecting leucocyte profiles in the little auk, a small Arctic seabird. J Ornithol 156:101-111. https://doi.org/10.1007/ s10336-014-1101-5

Jakubas D, Iliszko LMLM, Strøm H et al (2016) Foraging behavior of a high-Arctic zooplanktivorous alcid, the little auk, at the southern edge of its breeding range. J Exp Mar Bio Ecol 475:89-99. https://doi.org/10.1016/j.jembe.2015.11.010

Jakubas D, Wojczulanis-Jakubas K, Iliszko LM et al (2017) Habitat foraging niche of a High Arctic zooplanktivorous seabird in a changing environment. Sci Rep 7:16203. https://doi.org/10.1038/ s41598-017-16589-7

Jakubas D, Wojczulanis-Jakubas K, Iliszko LM et al (2020) Flexibility of little auks foraging in various oceanographic features in a changing Arctic. Sci Rep 10:8238. https://doi.org/10.1038/ s41598-020-65210-x

Jakubas D, Wojczulanis-Jakubas K, Petersen A (2022) A quiet extirpation of the breeding little auk Alle alle population in Iceland in the shadow of the famous cousin extermination. Sci of The Total Environ 808:152167. https://doi.org/10.1016/j.scitotenv. 2021.152167

Kampp K, Falk K, Pedersen CE (2000) Breeding density and population of little auks (Alle alle) in a Northwest Greenland colony. Polar Biol 23:517-521. https://doi.org/10.1007/s003000000115

Karnovsky NJ, Kwaśniewski S, Wẹsławski JM et al (2003) Foraging behavior of little auks in a heterogeneous environment. Mar Ecol Prog Ser 253:289-303. https://doi.org/10.3354/meps253289
Karnovsky N, Harding A, Walkusz W et al (2010) Foraging distributions of little auks Alle alle across the Greenland Sea: implications of present and future Arctic climate change. Mar Ecol Prog Ser 415:283-293. https://doi.org/10.3354/meps08749

Karnovsky NJ, Brown ZW, Welcker J et al (2011) Inter-colony comparison of diving behavior of an arctic top predator: implications for warming in the Greenland Sea. Mar Ecol Prog Ser 440:229-240. https://doi.org/10.3354/meps09351

Keslinka LK, Wojczulanis-Jakubas K, Jakubas D, Neubauer G (2019) Determinants of the little auk (Alle alle) breeding colony location and size in W and NW coast of Spitsbergen. PLoS ONE 14:e0212668. https://doi.org/10.1371/journal.pone.0212668

Kidawa D, Jakubas D, Wojczulanis-Jakubas K et al (2015) Parental efforts of an Arctic seabird, the little auk Alle alle, under variable foraging conditions. Mar Biol Res 11:349-360. https://doi.org/ 10.1080/17451000.2014.940974

Kidawa D, Barcikowski M, Palme R (2017) Parent-offspring interactions in a long-lived seabird, the Little Auk (Alle alle): begging and provisioning under simulated stress. J Ornithol 158:145-157. https://doi.org/10.1007/s10336-016-1382-y

Konarzewski M, Taylor J, Gabrielsen G (1993) Chick energy requirements and adult energy expenditures of dovekies (Alle alle). Auk 110:343-353

Kulaszewicz I, Wojczulanis-Jakubas K, Jakubas D (2017) Trade-offs between reproduction and self-maintenance (immune function and body mass) in a small seabird, the little auk. J Avian Biol 48:371-379. https://doi.org/10.1111/jav.01000

Kulaszewicz I, Wojczulanis-Jakubas K, Jakubas D (2018) Breeding phased dependent oxidative balance in a small High Arctic seabird, the little auk. J Avian Biol 49:e01702. https://doi.org/10. 1111/jav.01702

Kwasniewski S, Gluchowska M, Jakubas D et al (2010) The impact of different hydrographic conditions and zooplankton communities on provisioning Little Auks along the West coast of Spitsbergen. Prog Oceanogr 87:72-82. https://doi.org/10.1016/j.pocean.2010. 06.004

Kwasniewski S, Gluchowska M, Walkusz W et al (2012) Interannual changes in zooplankton on the West Spitsbergen Shelf in relation to hydrography and their consequences for the diet of planktivorous seabirds. ICES J Mar Sci 69:890-901. https://doi.org/10. 1093/icesjms/fss076

Legagneux P, Gauthier G, Berteaux D et al (2012) Disentangling trophic relationships in a High Arctic tundra ecosystem through food web modeling. Ecology 93:1707-1716. https://doi.org/10. 1890/11-1973.1

Literak I, Manga I, Wojczulanis-Jakubas K et al (2014) Enterobacter cloacae with a novel variant of ACT AmpC beta-lactamase originating from glaucous gull (Larus hyperboreus) in Svalbard. Vet Microbiol 171:432-435. https://doi.org/10.1016/j.vetmic.2014. 02.015

Moe B, Stempniewicz L, Jakubas D et al (2009) Climate change and phenological responses of two seabird species breeding in the high-Arctic. Mar Ecol Prog Ser 393:235-246. https://doi.org/ $10.3354 /$ meps08222

Møller EF, Johansen KL, Agersted MD et al (2018) Zooplankton phenology may explain the North Water polynya's importance as a breeding area for little auks. Mar Ecol Prog Ser 605:207-223. https://doi.org/10.3354/meps 12745

Mosbech A, Lyngs P, Lambert Johansen K (2017) Estimating little auk (Alle alle) breeding density and chick-feeding rate using video surveillance. Polar Res 36:1374122. https://doi.org/10.1080/ 17518369.2017.1374122

Mosbech A, Johansen KL, Davidson TA et al (2018) On the crucial importance of a small bird: the ecosystem services of the little auk (Alle alle) population in Northwest Greenland in a 
long-term perspective. Ambio 47:226-243. https://doi.org/10. 1007/s13280-018-1035-x

National Ice Center (NIC) and NSIDC (2010) Multisensor analyzed sea ice extent-Northern Hemisphere. In: Fetterer F, Savoie M, Helfrich S, Clemente-Colón P (eds) IMS daily Northern hemisphere snow and ice analysis at $4 \mathrm{~km}$ resolution data set. NSIDC, Boulder

Pacyna-Kuchta AD, Jakubas D, Frankowski M et al (2020) Exposure of a small Arctic seabird, the little auk (Alle alle) breeding in Svalbard, to selected elements throughout the course of a year. Sci Total Environ 732:139103. https://doi.org/10.1016/j.scito tenv.2020.139103

Piatt JF, Sydeman WJ, Wiese F (2007) Introduction: a modern role for seabirds as indicators. Mar Ecol Prog Ser 352:199-204. https:// doi.org/10.3354/meps07070

Ramírez F, Tarroux A, Hovinen J et al (2017) Sea ice phenology and primary productivity pulses shape breeding success in Arctic seabirds. Sci Rep 7:1-9. https://doi.org/10.1038/ s41598-017-04775-6

Renedo M, Amouroux D, Albert C et al (2020) Contrasting spatial and seasonal trends of methylmercury exposure pathways of Arctic seabirds: combination of large-scale tracking and stable isotopic approaches. Environ Sci Technol 54:13619-13629. https://doi. org/10.1021/acs.est.0c03285

Rosing-Asvid A, Hedeholm R, Arendt KE et al (2013) Winter diet of the little auk (Alle alle) in the Northwest Atlantic. Polar Biol 36:1601-1608. https://doi.org/10.1007/s00300-013-1379-4

Sæther BE, Bakke $\varnothing$ (2000) Avian life history variation and contribution of demographic traits to the population growth rate. Ecology 81:642-653. https://doi.org/10.2307/177366

Serreze MC, Barry RG (2011) Processes and impacts of Arctic amplification: a research synthesis. Glob Planet Change 77:85-96. https://doi.org/10.1016/j.gloplacha.2011.03.004

Skrzypek G, Wojtuń B, Richter D et al (2015) Diversification of nitrogen sources in various tundra vegetation types in the High Arctic. PLoS ONE 10:e0136536. https://doi.org/10.1371/journal.pone. 0136536

Smith NA, Clarke JA (2015) Systematics and evolution of the PanAlcidae (Aves, Charadriiformes). J Avian Biol 46:125-140. https://doi.org/10.1111/jav.00487

Steen H, Vogedes D, Broms F et al (2007) Little auks (Alle alle) breeding in a High Arctic fjord system: bimodal foraging strategies as a response to poor food quality? Polar Res 26:118-125. https:// doi.org/10.1111/j.1751-8369.2007.00022.x

Steinacher M, Joos F, Frölicher TL et al (2009) Imminent ocean acidification in the Arctic projected with the NCAR global coupled carbon cycle-climate model. Biogeosciences 6:515-533. https:// doi.org/10.5194/bg-6-515-2009

Stempniewicz L (1981) Breeding biology of the Little Auk, Plautus alle in the Hornsund region, SW Spitsbergen. Acta Ornithol 18:141-165

Stempniewicz L (1982) Body proportions in adults and fledgelings of the Little Auk. Acta Zool Cracoviensis 26:149-158

Stempniewicz L (1983) Hunting methods of the glaucous gull and escape maneuvers of its prey, the dovekie. J F Ornithol $54: 329-331$

Stempniewicz L (1986) Factors causing changes in the rhythm of attendance of the little auks, Plautus alle (L.) at a colony during the breeding season in Svalbard. Ekol Pol 34:247-263

Stempniewicz L (1990) Biomass of Dovekie excreta in the vicinity of a breeding colony. Colon Waterbirds 13:62-66. https://doi.org/ $10.2307 / 1521421$

Stempniewicz L (1993) The polar bear Ursus maritimus feeding in a seabird colony in Frans Josef Land. Polar Res 12:33-36. https:// doi.org/10.1111/j.1751-8369.1993.tb00420.x
Stempniewicz L (1995) Predator-prey interactions between Glaucous Gull Larus hyperboreus and Little Auk Alle alle in Spitsbergen. Acta Ornithol 29:155-170

Stempniewicz L (2001) BWP update. Little Auk (Alle alle). J Birds West Palearct 3:175-201

Stempniewicz L, Błachowiak-Samołyk K, Wesławski JM (2007) Impact of climate change on zooplankton communities, seabird populations and arctic terrestrial ecosystem-a scenario. Deep Res Part II Top Stud Oceanogr 54:2934-2945. https://doi.org/10. 1016/j.dsr2.2007.08.012

Stempniewicz L, Darecki M, Trudnowska E et al (2013) Visual prey availability and distribution of foraging little auks (Alle alle) in the shelf waters of West Spitsbergen. Polar Biol 36:949-955. https://doi.org/10.1007/s00300-013-1318-4

Stempniewicz L, Goc M, Głuchowska M et al (2021) Abundance, habitat use and food consumption of seabirds in the high-Arctic fjord ecosystem. Polar Biol 1:3. https://doi.org/10.1007/ s00300-021-02833-4

Taylor J (1994) Changes in body mass and body reserves of breeding Little Auks (Alle alle L.). Polish Polar Res 15:147-168

Taylor JRE, Konarzewski M (1989) On the importance of fat reserves for the little auk (Alle alle) chicks. Oecologia 81:551-558. https://doi.org/10.1007/BF00378968

Vogedes D, Eiane K, Båtnes AS, Berge J (2014) Variability in Calanus spp. abundance on fine- to mesoscales in an Arctic fjord: implications for little auk feeding. Mar Biol Res 10:437-448. https://doi. org/10.1080/17451000.2013.815781

Wassmann P, Duarte CM, Agustí S, Sejr MK (2011) Footprints of climate change in the Arctic marine ecosystem. Glob Chang Biol 17:1235-1249. https://doi.org/10.1111/j.1365-2486.2010. 02311.x

Welcker J, Harding AMA, Karnovsky NJ et al (2009a) Flexibility in the bimodal foraging strategy of a high Arctic alcid, the little auk Alle alle. J Avian Biol 40:388-399. https://doi.org/10.1111/j. 1600-048X.2008.04620.x

Welcker J, Steen H, Harding AM, Gabrielsen GW (2009b) Sex-specific provisioning behaviour in a monomorphic seabird with a bimodal foraging strategy. Ibis (Lond 1859) 151:502-513. https://doi.org/ 10.1111/j.1474-919X.2009.00931.x

Welcker J, Beiersdorf A, Varpe Ø, Steen H (2012) Mass fluctuations suggest different functions of bimodal foraging trips in a central-place forager. Behav Ecol 23:1372-1378. https://doi.org/10. 1093/beheco/ars131

Weslawski JM, Koszteyn J, Kwasniewski S et al (1999) Summer food resources of the little auk, Alle alle (L.) in the European Arctic seas. Polish Polar Res 20:387-403

Wẹsławski JM, Hacquebord L, Stempniewicz L, Malinga M (2000) Greenland whales and walruses in the Svalbard food web before and after exploitation. Oceanologia 42:37-56

Wojczulanis K, Jakubas D, Stempniewicz L (2005) Changes in the Glaucous gull predatory pressure on Little Auks in Southwest Spitsbergen. Waterbirds 28:430-435

Wojczulanis K, Jakubas D, Walkusz W, Wennerberg L (2006) Differences in food delivered to chicks by males and females of little auks (Alle alle) on South Spitsbergen. J Ornithol 147:543-548. https://doi.org/10.1007/s10336-006-0077-1

Wojczulanis-Jakubas K (2021) Being the winner is being the loser when playing a parental tug-of-war-a new framework on stability of biparental care. Front Ecol Evol 9:814. https://doi.org/10. 3389/fevo.2021.763075

Wojczulanis-Jakubas K, Jakubas D (2012) When and why does my mother leave me? The question of Brood desertion in the Dovekie (Alle alle). Auk 129:632-637. https://doi.org/10.1525/auk. 2012.12095 
Wojczulanis-Jakubas K, Jakubas D, Stempniewicz L (2008) Avifauna of Hornsund area, SW Spitsbergen: present state and recent changes. Polish Polar Res 29:187-197

Wojczulanis-Jakubas K, Jakubas D, Øigarden T, Lifjeld JTJT (2009a) Extrapair copulations are frequent but unsuccessful in a highly colonial seabird, the little auk, Alle alle. Anim Behav 77:433438. https://doi.org/10.1016/j.anbehav.2008.10.019

Wojczulanis-Jakubas K, Jakubas D, Stempniewicz L (2009b) Sexspecific parental care by incubating little auks (Alle alle). Ornis Fenn 86:140-148

Wojczulanis-Jakubas K, Jakubas D, Karnovsky NJNJ, Walkusz W (2010a) Foraging strategy of little auks under divergent conditions on feeding grounds. Polar Res 29:22-29. https://doi.org/10. 1111/j.1751-8369.2009.00145.x

Wojczulanis-Jakubas K, Svoboda A, Kruszewicz A, Johnsen A (2010b) No evidence of blood parasites in Little Auks (Alle alle) breeding on Svalbard. J Wildl Dis 46:574-578. https://doi.org/10.7589/ 0090-3558-46.2.574

Wojczulanis-Jakubas K, Dynowska M, Jakubas D (2011a) Fungi prevalence in breeding pairs of a monogamous seabird-little auk, Alle alle. Ethol Ecol Evol 23:240-247. https://doi.org/10.1080/ 03949370.2011 .566582

Wojczulanis-Jakubas K, Jakubas D, Welcker J et al (2011b) Body size variation of a high-Arctic seabird: the dovekie (Alle alle). Polar Biol 34:847-854. https://doi.org/10.1007/s00300-010-0941-6

Wojczulanis-Jakubas K, Jakubas D, Kidawa D, Kośmicka A (2012) Is the transition from biparental to male-only care in a monogamous seabird related to changes in body mass and stress level? J Ornithol 153:793-800. https://doi.org/10.1007/s10336-011-0796-9

Wojczulanis-Jakubas K, Jakubas D, Chastel O (2013) Behavioural and hormonal stress responses during chick rearing do not predict brood desertion by female in a small Arctic seabird. Horm Behav 64:448-453. https://doi.org/10.1016/j.yhbeh.2013.07.001

Wojczulanis-Jakubas K, Jakubas D, Chastel O (2014a) Different tactics, one goal: initial reproductive investments of males and females in a small Arctic seabird. Behav Ecol Sociobiol 68:1521-1530. https://doi.org/10.1007/s00265-014-1761-4

Wojczulanis-Jakubas K, Jakubas D, Kulaszewicz I et al (2014b) Influence of primary reproductive investments on blood biochemistry, leukocyte profile, and body mass in a small Arctic seabird. Auk 131:743-755. https://doi.org/10.1642/AUK-14-62.1

Wojczulanis-Jakubas K, Kilikowska A, Harding AMA et al (2014c) Weak population genetic differentiation in the most numerous Arctic seabird, the little auk. Polar Biol 37:621-630. https://doi. org/10.1007/s00300-014-1462-5

Wojczulanis-Jakubas K, Jakubas D, Chastel O, Kulaszewicz I (2015a) A big storm in a small body: seasonal changes in body mass, hormone concentrations and leukocyte profile in the little auk
(Alle alle). Polar Biol 38:1203-1212. https://doi.org/10.1007/ s00300-015-1687-y

Wojczulanis-Jakubas K, Kilikowska A, Fort J et al (2015b) No evidence of divergence at neutral genetic markers between the two morphologically different subspecies of the most numerous Arctic seabird. Ibis (Lond 1859) 157:787-797. https://doi.org/10. 1111/ibi.12294

Wojczulanis-Jakubas K, Araya-Salas M, Jakubas D (2018a) Seabird parents provision their chick in a coordinated manner. PLoS ONE 13:e0189969. https://doi.org/10.1371/journal.pone.0189969

Wojczulanis-Jakubas K, Drobniak SM, Jakubas D et al (2018b) Assortative mating patterns of multiple phenotypic traits in a longlived seabird. Ibis (Lond 1859) 160:464-469. https://doi.org/10. 1111/ibi.12568

Wojczulanis-Jakubas K, Jakubas D, Kulpińska-Chamera M, Chastel O (2018c) Sex- and breeding stage-specific hormonal stress response of seabird parents. Horm Behav 103:71-79. https:// doi.org/10.1016/j.yhbeh.2018.06.005

Wojczulanis-Jakubas K, Jiménez-Muñoz M, Jakubas D et al (2020a) Duration of female parental care and their survival in the little auk Alle alle - are these two traits linked? Behav Ecol Sociobiol 74:82. https://doi.org/10.1007/s00265-020-02862-9

Wojczulanis-Jakubas K, Wąż P, Jakubas D (2020b) Little auks under the midnight sun: diel activity rhythm of a small diving seabird during the Arctic summer. Polar Res 39:3309. https://doi.org/10. 33265/polar.v39.3309

Zmudczyńska K, Olejniczak I, Zwolicki A et al (2012) Influence of allochtonous nutrients delivered by colonial seabirds on soil collembolan communities on Spitsbergen. Polar Biol 35:1233-1245. https://doi.org/10.1007/S00300-012-1169-4/FIGURES/4

Zonn IS, Kostianoy AG, Semenov AV (2017) Arctic climate impact assessment. The Western Arctic Seas Encyclopedia. Springer, Cham, pp 17-17

Zwolicki A, Zmudczyńska-Skarbek K, Matuła J et al (2016a) Differential responses of Arctic vegetation to nutrient enrichment by plankton- and fish-eating colonial seabirds in Spitsbergen. Front Plant Sci 07:1-14. https://doi.org/10.3389/fpls.2016.01959

Zwolicki A, Zmudczyńska-Skarbek K, Richard P, Stempniewicz L (2016b) Importance of marine-derived nutrients supplied by Planktivorous seabirds to high Arctic Tundra plant communities. PLoS ONE 11:e0154950. https://doi.org/10.1371/journal. pone. 0154950

Publisher's Note Springer Nature remains neutral with regard to jurisdictional claims in published maps and institutional affiliations. 